\title{
Heroine in the Narratives of Pakistani Cinema
}

\section{Saqlain Zaidi*}

\begin{abstract}
This paper explores the portrayal of Pakistani women in the narratives of Pakistani film and investigates whether those portrayals are close to real life. Starting from a chooi-mooi girl to the brave Sara of Shoaib Mansoor's Verna who takes revenge of her rape, Pakistani heroine has come a long way from being depicted mostly as passive, dependent on men, and enmeshed in relationships or housework ${ }^{1}$ to an active, independent and a rebellious individual. This paper explores how the story worlds of different heroines, although presented in a heightened reality, are in fact reflective of real problems and desires. The stylistic device of lifting these story worlds of heroines to an above-reality level allows the privacy to acknowledge they exist without feeling publicly challenged. ${ }^{2}$
\end{abstract}

Key words: Women and Pakistani Cinema, Chooi -mooi girl (very delicate), new content of films

*Assistant Professor in Media Science Department at SZABIST, Karachi where he teaches screenwriting, film theory and literature. Email: yourdost@hotmail.com

1 Donald M Davis, "Portrayals of Women in Prime-Time Network Television: Some Demographic Characteristics," Sex Roles 23, no. 5 (1990): 325-32, https://doi.org/10.1007/BF00290052

2 Wajiha Raza Rizvi, "Visual Pleasures in Pakistani Cinema," in The London Film and Media Reader 1: Essays from FILM AND MEDIA 2011. The First Annual London Film and Media Conference, ed. Phillip Drummond (London: The London Symposium \&Academic Conferences London Ltd, 2013), pp.219-26, www.thelondonfilmandmediaconfe rence.com 


\section{Introduction}

The way Pakistani Cinema has portrayed women does not conform to their real role in the society. It portrays them as unthinking, dependent and submissive beings with reproduction as their fundamental role (with few exceptions we will explore in this paper). Cinematic screens do not represent their real-life feelings and behaviors are shown more in fantasy roles than their real life. Common woman in the society finds it hard to relate herself to the depiction of females in the media. ${ }^{3}$ In this paper will explore the exceptional roles portrayal of heroines that differ from the above recent findings.

\section{Film-makers of Pakistan}

In Pakistan, majority of successful directors sought none formal training in film from academic institutions, yet they knew how to read the pulse of the society. They presented contemporary social values, aspirations and desires of the society through their mainstream commercial cinema. They knew what Pakistani audience was looking for and they knew it quite well that commercial cinema is the parameter to gauge the overall psyche of any nation. ${ }^{4}$ For Deleuze, images and sequences have the power to replace, obliterate, and recreate the object itself. Cinema completely reinterpret the objects it represents, and it can create a new way of seeing objects. ${ }^{5}$

\section{What Cinema Has Become}

Cinema in the twenty-first century has gained the ability to conceive its own literature and vocabulary in the form of a visual image. Subsequently, filmmaker has earned the right to become first author himself instead of borrowing from written fiction. ${ }^{6}$ Film has become a new thinking ${ }^{7}$ and powerfully reinterpret the objects it represents and can create a new way of seeing objects. ${ }^{8}$ Cinema performs a very important social function, and that is to bring people of different classes and mindsets under the same roof at the same time. Within minutes people from

3 Institute of Policy Studies, "Portrayal of Women in Media," Institute of Policy Studies Islmabad, 2009, https://www.ips.org.pk/portrayal-of-women-in-media/

4 Irfan Urfi, "Pakistani Cinema: Islami Iqdaar Ke Farogh Se Farogh-e-Jehad Tak," in Tarikh, Tehzeeb Aur Samaaj: Naye Adab Ke Tanaazur Maen, ed. Qasim Yaqoob (Karachi: City Book Point, 2015), p.276

5 Tal S Shamir, Cinematic Philosophy (New York: Palgrave Macmillan, 2018), p.119

6 "Guftagoo with Gulzar - YouTube," Rajya Sabha TV, 2012, https://www.youtube.com/watch?v=eJQ0sh-BU_8.

7 Tal S Shamir, Cinematic Philosophy (New York: Palgrave Macmillan, 2018), p.118

$8 \quad$ Ibid.,p.119 
different segments of society laugh at the same jokes and shedding tears on the same tragedy. ${ }^{9}$

\section{Heroine of a Pakistani Film}

In the early days of Pakistani cinema, the attitude to films was somewhat puritanical. The early films promoted the norms of the civilised, Urdu-speaking elites of Delhi and Lucknow through social narratives which have been eclipsed by the vulgar comedy, 'dirty' dancing, and charismatic Punjabi villainy of the last three decades. The early Pakistani films promoted the legendary chhooi-mooi girl who surrendered herself to the desires of the male viewer. The chhooi-mooi girl has been replaced by the fragmented exhibitionism of the contemporary 'rain dancer'. These bold and beautiful women have superseded the stereotypical symbols. ${ }^{10}$ Within this polarization there are some powerful characters, though they are few, portrayed by daring heroines in the last many decades.

\section{Laali (Musarrat Nazir) of M.J.Rana's Yakke Wali (1957)}

One of the critical roles played by any female artist in the history of Pakistani cinema was by Mussarat Nazir in (1957) film, "Yakke Wali" directed by M.J. Rana. Laali of Yakke Wali was represented as a woman who had to disguise herself as a man to find herself work. On one hand, this film showed a character of a strong woman who will face the outer world bravely, but (sadly) it emphasized on the notion it is impossible for a woman to work freely due to her sex and for the sake of work she can't survive if she is a woman, thus disguising herself as a man. ${ }^{11}$

\section{Jamila (Shamim Ara) \& Razia (Nayyar Sultana) of S.M.Yousuf's Saheli (1960)}

The landscape of Pakistani cinema, however, saw a glimpse of change with movies like Saheli (1960) directed by S.M.Yousuf, which started the evolution of another type of woman. Regarding Saheli, the theme that is not given the deserved recognition is the social bonding of the two female protagonists, and the on-screen friendship between the two friends Jamila (Shamim Ara) and Razia (Nayyar Sultana) compel them to marry the same man, so they may be together. This film

9 Irfan Urfi, "Pakistani Cinema: Islami Iqdaar Ke Farogh Se Farogh-e-Jehad Tak," in Tarikh, Tehzeeb Aur Samaaj: Naye Adab Ke Tanaazur Maen, ed. Qasim Yaqoob (Karachi: City Book Point, 2015), p.275

10 Wajiha Raza Rizvi, "Visual Pleasures in Pakistani Cinema," in The London Film and Media Reader 1: Essays from FILM AND MEDIA 2011. The First Annual London Film and Media Conference, ed. Phillip Drummond (London: The London Symposium \&Academic Conferences London Ltd, 2013),p. 220, www.thelondonfilmandmediaconference.com.

11 A.F. Daudpoto, "Trends and Themes in Pakistani Cinema," SACS 3, no. 1 (2010) pp.17-25 
opens up an argument about women's depiction in popular media in Pakistan to create a different archive of women's cultural politics and histories. ${ }^{12}$

\section{Laila (Musarrat Nazir) in Khaleel Qaiser's 'Shaheed' (The Martyr) (1962)}

Khalil Qaiser (writer, director) and Riaz Shahid (writer, director) emerged on the horizon of the Pakistani silver screen during the sixties and Khaleel Qaiser directed 'Shaheed' (The Martyr) in 1962. The political references in the film are not vague allusions and it deals with an underground nationalist movement to foil British designs to gain control over oil-rich Arab land of 1922.13 The important character of the Arab dancer Laila (Musarrat Nazir), a bold and beautiful woman who enchanted the audience as a dancing girl on the tune of Habibi Hayya Hayya (You are my love come on come on). In the beginning she was the partner in crimes with this guest researcher and traveler, Ajnabi but later she became a part of the underground nationalist movement for the rights of people to their soil. When she argued with Ajnabi he taunts at her by saying "watan parasti ka bhoot sawar ho gya hae" (the demon of nationalism has overwhelmed you). And determined Laila replied "humesha kamzoer haath he na-insaafi ke khilaf jihad kartay haen ajnabi (it is those weak hands that always fight against injustice stranger). "mujhay apnay gunahoen ki qasam aaj mae apni zindagi dae kur dunya ki sub se baree naeki khareednay aayi hoon (I swear upon my sins that by giving my life today I will fetch the best of good deeds). And then at the climax of the film Laila died as suicide killer. She pours oils on her clothes and jumps into the oil well that was supposed to supply oil to western powers in coming times within the landscape of film. In her suicide attempt in the oil field, only she died, and she attempted this for her people under the influence of patriotism. So, film offers no rationale to any collateral damage by showing killing of innocent people because of suicide killing out there. ${ }^{14}$

\section{Najma (Zeba) of Pervaiz Malik's Armaan (1966)}

This was a woman "profound" and prudent who would not owe her knowledge of the world to her man, but this image of woman was never more "perfect", more vivid and more widely accepted than as Najma the heroine of Arman. ${ }^{15}$ Najma, an orphan, living in the home of her wealthy but less than kind relatives, her status is reduced to that of a house-maid, but she does not care about her less than pleasant living conditions as long as she has a home to live in. Happily, she goes out to fetch vegetables and escort her rich cousins whenever they want to step out. When one of

12 Kamran Asdar Ali, “On Female Friendships - DAWN.COM,” Dawn, 2014, https://www.dawn.com/news/1122839.

13 Mushtaq. Gazdar, Pakistan Cinema: 1947-1997 (Karachi; New York: Oxford University Press, 1997),p. 90

14 Urfi, "Pakistani Cinema: Islami Iqdaar Ke Farogh Se Farogh-e-Jehad Tak.", p. 282

15 Parvaiz Malik, Armaan (Pakistan: Film Arts, 1966) 
them gives birth to an illegitimate child, Najma skillfully takes charge of the matter, arranging for the baby to live without being discovered. Later, when she meets the 'right' man she accepts his proposal with little hassle. As their marriage is about to take place, the family discovers the baby, thanks to the villainy of Najma's jealous aunt. This movie brings us back to the image of women as an oppressed victim and talks about the norms of society where only those women that loves to abide by the rules of home shall be permitted to marry. Pervaiz humorously shows the world of hypocrisy and guilt. The guilt is where women would hide her sorrows and pull another woman to her sins, whereas men are busy in their "shandaar mustaqbil"(bright future). No one is there to question men for what they have done but there is always someone to question women for what she has done along with the consent of a man. ${ }^{16}$

\section{Anjuman (Rani) of Hassan Tariq's Anjuman (1970)}

One of the self-taught, finest directors of Pakistani cinema Hassan Tariq directed his first movie Neend (Sleep) in the 1950s when he was only seventeen. ${ }^{17}$ Yes, he too was not formally trained from any academic institution of film and learned the craft while working with masters of fifties like Shaukat Husain Rizvi and W.Z.Ahmed. His later work Anjuman (1970) deal with courtesans. Anjuman, played by Rani, who falls in love with Asif, played by Waheed Murad. Society has a difficult time forgiving woman for being involved in such actions even though a man is an equal participant in it. She was given a sinful appearance when she would entertain, but the males who would willingly enjoy this entertainment were not shown committing an immoral deed. In fact, after the family finds out Asif's secret meetings with Anjuman, instead of treating him differently, they will forgive his sins and accept him back. However, nobody is ready to overlook Anjuman's life as a prostitute. Society wants Anjuman to remember herself as a 'tawaif' (courtesan) who under the public's eye would always remain an immodest and shameful woman not worthy of marrying anyone. ${ }^{18}$

\section{Amna (Nisho) of Riaz Shahid's Yeh Aman (This Peace) (1971)}

Riaz Shahid had an uncanny talent for writing dialogues in rhythmic form and through a jigsaw of vocabulary that would captivate the audience completely. He was the first screenwriter; He wrote and directed Yeh Aman (This Peace) which showed the struggle of the Kashmiris. ${ }^{19}$ Yeh Aman seems like an honest attempt at going against the dominant sectarianism of the time. This is clear by the choice of

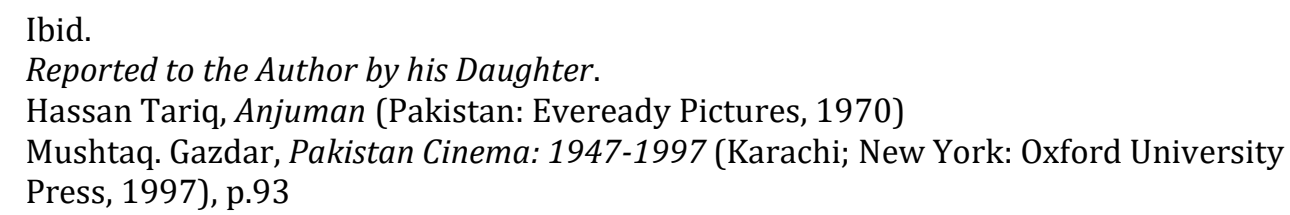

Ibid.

Reported to the Author by his Daughter.

Hassan Tariq, Anjuman (Pakistan: Eveready Pictures, 1970)

Mushtaq. Gazdar, Pakistan Cinema: 1947-1997 (Karachi; New York: Oxford University

Press, 1997), p.93 
relationships in the film, whereby strong bonds of friendship and love are projected between a Hindu and a Muslim household. When the Indian Colonel invaded the heroin's home as he thought Amna (Nisho) possessed details about the freedom fighters, she convinced her father to cut her tongue so that she could play her role successfully in the Kashmir struggle by offering this sacrifice. ${ }^{20}$

\section{Heroine of Post9/11 Contemporary Pakistani Cinema}

In the last ten years, starting from Shoaib Mansoor's Khuda ke Liyae the portrayal of heroine has gone through major changes. The two popular movies that came to mind are Khuda Ke Liye (2007) and BOL (2011). Khuda Ke Liye, a movie by Shoaib Mansoor, depicts the dilemma of the well-educated, progressive and liberal Pakistanis living in post 9/11 environment. This movie shows contrasting roles for women. On the one side there are two liberal minded "modern" women. One, a Muslim girl (Iman Ali) who grew up in the UK with a western mindset but is tricked into marrying her fundamentalist Muslim cousin and moving to a village in Afghanistan by her father and where she is portrayed as a victim who fights back showing her modern mindset that women can stand up for themselves and giving hope to Muslim women everywhere. One the other hand there is the older generation's mother who lets steps aside and let's injustice happen. ${ }^{21}$

The other film BOL (2011) is about Hakeem Saheb (Manzar Sehbai) who has seven daughters and a boy who is not really a boy. He is a grumpy old man who hates everyone in his family and uses religion to control them. One of the daughters, Aisha (Mahira Khan) was in love with her neighbor Mustafa (Atif Aslam) and the girl's father thought love before marriage was a great sin. He was more concerned with his reputation that the people in the society will look at him with great disrespect if they find out his daughter is having an affair with a guy. The outcome was that the girl eloped and marry the guy she loved against her father's will. This movie focuses on the oppression of women and how one sister Marium (Humaima Malick) stands up against her father to protect her family. The movie also shows the younger sister Ayesha who dares to fall in love and dreams of becoming a singer. ${ }^{22}$

Both these films focus on real-life issues of women but also show how women can stand up for themselves and give hope to Muslim women. It also show these women as the "hero" in the movie who doesn't wait around for a man to come and save them. Breaking the patriarchal perception of "women are weak" and presenting a new kind of women. ${ }^{23} 24$

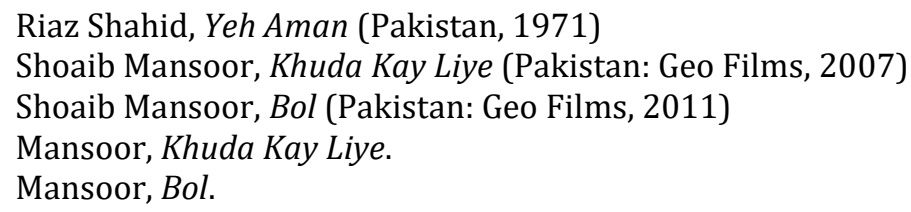




\section{Conclusion}

The treatment of content offered by recent Pakistani films is one ray of hope as the veteran film and magazine's editor at Dawn, Hasan Zaidi shared in Herald in January 2018. It all began with a notorious slap in Syed Noor's Chain Aaye Na (2017). In the film, the hero Rayan (Shehroz Sabzwari) slaps the heroine Ruba (Sarish Khan) thrice to teach her a lesson and despite this slap, or because of it, the heroine falls in love with her abuser. A few months later, in Punjab Nahin Jaungi (2017), Fawad Khagga (Hunayub Saeed), a feudal, also slaps his highly educated wife Amal (Mehwish Hayat) but the result is that she walks out of their marriage and both their families condemn Fawad's act. Eventually, Fawad has to beg for forgiveness from his wife, which she grants him. In Verna (2017), which revolves around a rape and the misunderstandings it creates between the rape survivor Sara (Mahira Khan) and her husband Aami (Haroon Shahid), Mahira's character also gets slapped by her urbane husband. But her response to this bit of unexpected abuse is that, once she recovers her wits, she pummels him in the face, leaving him dazed and bloodied. The film clarifies that this response by Sara's character is justified. In effect, in just one year we have witnessed three slaps to female characters with progressively more assertive responses. From submissive acceptance in Chain Aaye $\mathrm{Na}$, to outrage in Punjab Nahin Jaungi, to take-no-crap in Verna, Pakistani film-makers have shown that mindsets can, in fact, change pretty quickly. At some level, one must consider this social progress. ${ }^{25}$

25 Hasan Zaidi, "What Makes The Revival of Pakistani Cinema An Uphill Task," Herald, 2018, https://herald.dawn.com/news/1153991. 
Jhss, Vol. 10, No. 2 , July to December, 2019

\section{References}

Ali, Kamran Asdar. "On Female Friendships - DAWN.COM." Dawn, 2014. https://www.dawn.com/news/1122839.

Daudpoto, A.F. "Trends and Themes in Pakistani Cinema." SACS 3, no. 1 (2010): 1725.

Davis, Donald M. "Portrayals of Women in Prime-Time Network Television: Some Demographic Characteristics." Sex Roles 23, no. 5 (1990): 325-32. https://doi.org/10.1007/BF00290052.

Gazdar, Mushtaq. Pakistan Cinema: 1947-1997. Karachi; New York: Oxford University Press, 1999.

"Guftagoo with Gulzar - YouTube." Rajya Sabha TV, 2012.

https://www.youtube.com/watch?v=eJQ0sh-BU_8.

Institute of Policy Studies. "Portrayal of Women in Media." Institute of Policy Studies Islmabad, 2009. https://www.ips.org.pk/portrayal-of-women-in-media/.

Malik, Parvaiz. Armaan. Pakistan: Film Arts, 1966.

Mansoor, Shoaib. Bol. Pakistan: Geo Films, 2011.

——_. Khuda Kay Liye. Pakistan: Geo Films, 2007.

Reported to the Author by His Daughter, 2017.

Rizvi, Wajiha Raza. "Visual Pleasures in Pakistani Cinema." In The London Film and Media Reader 1: Essays from FILM AND MEDIA 2011. The First Annual London Film and Media Conference, edited by Phillip Drummond, 219-26. London: The London Symposium \&Academic Conferences London Ltd, 2013.

www.thelondonfilmandmediaconference.com.

Shahid, Riaz. Yeh Aman. Pakistan, 1971.

Shamir, Tal S. Cinematic Philosophy. New York: Palgrave Macmillan, 2018.

Tariq, Hassan. Anjuman. Pakistan: Eveready Pictures, 1970.

Urfi, Irfan. "Pakistani Cinema: Islami Iqdaar Ke Farogh Se Farogh-e-Jehad Tak." In Tarikh, Tehzeeb Aur Samaaj: Naye Adab Ke Tanaazur Maen, edited by Qasim Yaqoob, 272-93. Karachi: City Book Point, 2015.

Zaidi, Hasan. "What Makes The Revival of Pakistani Cinema An Uphill Task." Herald, 2018. https://herald.dawn.com/news/1153991. 